\title{
Article \\ The Sliding Scale between Usufruct and Ownership: The Example of Swedish Multi-Family Housing
}

\author{
Anna Granath Hansson*iD, Peter Ekbäck and Jenny Paulsson \\ Department of Real Estate and Construction Management, KTH Royal Institute of Technology, Teknikringen 10B, \\ 10044 Stockholm, Sweden; peter.ekback@abe.kth.se (P.E.); jenny.paulsson@abe.kth.se (J.P.) \\ * Correspondence: agh@kth.se; Tel.: +46-8-790-76-76
}

\begin{abstract}
This paper aims to elucidate the sliding scale between usufruct and ownership by applying a property rights framework to three Swedish forms of tenure in multifamily housing. The framework deconstructs the bundles of rights of rental, tenant-ownership and ownership to highlight commonalities and differences connected to the right to use and exclude, the right to transfer and the right to the value. It is concluded that the three tenure forms have many traits in common but that there are distinct differences in some areas, most notably in connection to the right to the value. The property rights framework applied in the study may be applicable also on a general level as a method to analyze and compare tenures of different types in different countries. Further, ways to improve the framework and cover more facets of outcomes of property rights patterns are suggested.
\end{abstract}

Keywords: tenure forms; property rights; rental; tenant-ownership; ownership

Citation: Granath Hansson, A.; Ekbäck, P.; Paulsson, J. The Sliding Scale between Usufruct and Ownership: The Example of Swedish Multi-Family Housing. Land 2021, 10 , 311. https://doi.org/10.3390/ land10030311

Academic Editor: Liz Alden Wily

Received: 1 February 2021

Accepted: 15 March 2021

Published: 18 March 2021

Publisher's Note: MDPI stays neutral with regard to jurisdictional claims in published maps and institutional affiliations.

Copyright: (c) 2021 by the authors. Licensee MDPI, Basel, Switzerland. This article is an open access article distributed under the terms and conditions of the Creative Commons Attribution (CC BY) license (https:// creativecommons.org/licenses/by/ $4.0 /)$.

\section{Introduction}

Approximately half of the Swedish population lives in multifamily housing [1]. There are three main tenures: ownership, tenant-ownership and rental. Of the 2.3 million apartments in multifamily housing, 1.3 million are rental and 970,000 tenant-ownership [2]. Ownership has only been possible since 2009 when a law with such purpose was introduced but has been slow to establish. The current number of ownership apartments is 2382 [3]. Multifamily housing in Sweden is owned by tenant-ownership associations (42\%), municipal housing companies $(27 \%)$, limited companies $(21 \%)$ and other private and legal persons $(10 \%)[3]$.

These tenure forms have developed over time and have both similarities and differences in their form and legal regulations. The forms have also changed and developed due to changes in society, policies, etc. It is not always easy for housing consumers to understand the different forms and what separates them. For example, as a reason for why the rather new apartment ownership form has not gained much popularity so far has been mentioned the difficulties for the housing consumer to understand how it differs from the tenant-ownership apartment. Some people also seem to believe that they own their tenant-ownership apartment with full ownership rights. The forms are not that distinctly separated, which has been discussed, e.g., by Paulsson [4], who claims that the Swedish forms in several ways seem to be rather similar between each other.

The aim of this paper is to present the first stage of a research project focusing on elucidating the sliding scale between usufruct and ownership through the example of multifamily housing. This part of the project is an analysis of the property rights characteristics of the three main Swedish tenure forms. In addition, we outline potential future research that can deepen the analysis and enhance understanding of property rights patterns also in other contexts.

The article starts with an overview of property rights theory, then describes the three most common forms of tenure and their legal frameworks, discusses them out of the 
defining aspects of property rights theory and last conclusions are drawn, and future research is outlined.

\section{Materials and Methods}

\subsection{Methods}

The research was carried out by a literature study combined with a comparative case study. A theoretical framework based on Ekbäck [5] was developed regarding property rights and the powers included in these. This framework was applied to a case study, including the Swedish tenure forms in multifamily housing. Three common distinct types of Swedish tenure forms were selected, and by applying the property rights framework on these forms and their legal features, it was possible to test the framework in order to see whether it may be applicable on a more general level, as a method to analyze and compare different types of tenure, both nationally and internationally. Tax issues have been omitted.

\subsection{Ownership to Real Property}

A starting point for a closer analysis of the different tenure forms in Swedish multifamily housing can be to examine the ownership concept from a property rights perspective. According to property rights theory [6], the ownership concept is not an indivisible entity. On the contrary, it can be described as a bundle of various rights and obligations, which the law, at any given point in time, confers on the owner of real property in relation to other individuals (cf. $[7,8]$ ).

Ownership is thus a legal institution the content, of which at any point in time is defined by legislation. Ownership of real property in Sweden is negatively determined, i.e., it comprises all powers not circumscribed by law and other regulations, which correlates with the structure of ownership institutions in most other European legal systems (cf. [9]).

One such general restriction that typically exists in the Swedish legislation-as well as in other Western European systems-is a requirement for public assessment and permission when major alterations of the current land use are intended. For instance, the erection of new buildings requires a building permit, according to the provisions in Plan-och bygglagen (the planning and building act). If an application for a building permit is denied, the property owner receives no compensation since the right to erect new buildings, due to the provisions in the planning and building act, is not a right included in the ownership of real property. Tenure forms, as institutions, can have "significant effect on what is built, where, its price and quality, for whom the housing is built [ ... ], the morphology of housing estates, and so on" ([10], p. 99).

The content of ownership may also decrease due to specific restrictions in zoning regulations regarding permitted land uses for defined areas. One property may contain, for example, an existing building with cultural-historical values that are protected by restrictive regulations regarding alterations and maintenance. Obviously, planning regulations may also increase the content of ownership, as will be the case where an undeveloped property is zoned for building development. Further, regulations related to the use of the property may also alter the contents of ownership. One example is regulations of subletting; another is legally binding divisions of costs and responsibilities related to common spaces.

As legislation is reformed and amended, land use plans and regulations are modified, and rights are vested/revoked and granted, likewise will the content of ownership to a specific unit of real property exhibit a corresponding elasticity over time.

Even though the content of ownership is not a foregone conclusion, certain powers must be included - to a greater or lesser extent-if the term ownership is to be of any relevance [11]. According to Ekbäck ([5], p. 58), these elementary powers include:

- The right to use the property;

- The right to exclude others from using the property;

- The right to transfer the property;

- The right to the value of the property. 


\subsection{Limited Rights and Different Tenure Forms}

Ownership can be contrasted with partial or limited real property rights, such as easements, mortgage rights, leaseholds, pre-emption rights, etc., whose content instead is defined in positive terms by contracts, public decisions, or in legal statutes.

From a property rights perspective, these limited rights can be considered a narrower and more restricted bundle of rights in comparison to full ownership rights. They may, e.g., be limited in time and to a specific use of the property, while the owner still has access to the remaining powers of ownership [12].

Some forms of limited rights are defined and sanctioned by legislation, which can be labeled tenure forms. For multifamily housing in the Swedish legislation, the major tenure forms are: rental tenancy, tenant-ownership and ownership. (For the sake of completeness, additional tenure forms do exist, such as cooperative rental rights and co-ownership (of which the latter is not yet regulated in legislation). These tenure forms are, however, rather uncommon and will not be included in the following analyses.)

The structure of property rights in these different tenure forms are of varying extent and composition, regarding the right to use and exclude others from the property, the right to transfer the property, and the right to the value of the property. In the following, we will concentrate on certain rights connected thereto:

(A) The right to use and exclude: (1) the duty of care and consideration, (2) the responsibility for the condition and standard of the apartment and the building, (3) the right to current use and to altered use, (4) the right to exclude and (5) security of tenure;

(B) The right to transfer: (1) transfer of the apartment and (2) subletting of the apartment; (C) The right to the value: (1) transfer price, (2) rent and management costs and (3) income from subletting

In the following sections, this theoretical framework will be applied for a closer exploration and analysis of these major tenure forms available in the Swedish legislation for multifamily housing.

However, before moving on to the analysis of formal property rights, it should be pointed out that the effect of institutions, such as tenure forms, is not only influenced by formal rules but also by informal rules and norms. To understand how people interpret rules and why they choose to follow them, their incentives and disincentives must be explained, as well as how the rules are interpreted and valued [13]. North [14] argues that "since it is the norms that provide legitimacy to the set of rules [ ... ] both institutions and belief systems much change for successful reform since it is the mental models of the actors that will shape choices". Mandič and Hrast [15] show in their recent study that the impact of property law may have lesser weight than informal behavioral patterns. The political process of defining and enforcing property rights can be decisive because of the distributional implications of different property rights allocations [16]. Further, Grossi and Dignum [17] identify different levels of abstraction of norms and norm-implementing proceedings, which may render the translation of norms into proceedings difficult. Hence, to better understand tenures, the herein contained analysis of formal property rights will be supplemented with an analysis of less transparent parts of these institutions in the form of norms and informal rules, which will be discussed below.

\subsection{Rental/Tenancy}

When a property owner enters into an agreement with someone whereby buildings or parts of buildings (apartments) are granted for use in return for payment, the tenure form is called tenancy or rental tenure. The statutory provisions on tenancy are assembled in the Jordabalken (land code), Chapter 12, which is popularly referred to as "hyreslagen" (the rent act).

The natural or legal person who owns the building and lets part of it is called the lessor, and the holder of the tenancy right is called the tenant. The provisions on rent are in principle mandatory to the benefit of the tenant, i.e., it is not possible to reach an agreement on deviations from the provisions if it involves a deterioration for the tenant. This is 
an expression of the legislator's efforts to safeguard and protect the conceived weaker part [18]. Tenancy disputes are mediated and arbitrated by the regional rent tribunal, which has a court-like composition and procedure for assessments and verdicts (More detailed provisions are stipulated in the Lag om arrendenämnder och hyresnämnder (act on tenancy and rent tribunals)).

\subsubsection{The Right to Use and Exclude}

The tenant has the right to use the apartment for residential purposes in accordance with the rental agreement. However, the tenant may not use the apartment for any other purpose. Minor deviations that are of no significance to the lessor are still permitted. Residential tenants also have the right to carry out painting, wallpapering and similar measures in the apartment at their own expense. Should the value of the apartment thereby decrease, however, the lessor is entitled to compensation for the damage?

As a tenant, you also have obligations towards the lessor and other tenants. The tenant must take care of the apartment and its fixtures and is obliged to compensate for any damage that arises through his or her own fault or through negligence or neglect by someone who belongs to the household or is visiting or by someone else accommodated in the apartment. When the tenant uses the apartment, he or she must further ensure that persons living in the surroundings are not exposed to disturbances. When using the apartment, the tenant must also otherwise observe everything that is required to maintain health, order and good conditions within the property. The tenant may also not accommodate outsiders in the apartment if this may entail detriment to the lessor.

If the tenant does not follow the above rules, he or she may be liable for damages. In the event of more serious offenses, the tenancy can be forfeited, which means that the lessor can immediately terminate the tenancy agreement.

Without the tenant's permission, unauthorized persons have no right to reside in or use the apartment and the spaces covered by the rental agreement. In certain situations, however, the lessor has the right to gain access to the apartment, e.g., to exercise necessary supervision or carry out improvement work.

Rental tenure connotes that the lessor has a far-reaching responsibility for the standard and condition of the apartment, as well as for maintenance and day-to-day management. According to the main principle, the lessor must, on the possession date, provide the apartment in such a condition that, according to the general view in the locality, it is fully usable for the intended purpose. Furthermore, the lessor must keep the apartment in the corresponding condition during the rental period. At reasonable time intervals, the lessor must, e.g., take care of wallpapering, painting and other customary repairs due to the deterioration of the apartment from age and use.

If the lessor does not fulfill this maintenance responsibility, the rent tribunal may order the lessor to remedy the deficiencies through a remedial injunction. In cases where a residential apartment has more serious deficiencies regarding standards, the rent tribunal can issue an improvement order. Both types of injunctions can be combined with contingent fines.

Leases are normally covered by security of tenure, which in principle means that the tenant has the right to have the lease prolonged even when the contract period has expired. In the case of residential tenancy, there is so-called direct protection of possession, which means that the lease can only be terminated in certain exceptional cases. These cases can, e.g., include that the house is to be demolished, that the tenant has acted to the severe detriment of the property owner or other tenants, that the apartment is no longer to be used for housing, or that the lessor needs the apartment as housing for him- or herself.

\subsubsection{The Right to Transfer}

The main principle is that a tenant may not transfer the tenancy to someone else without the lessor's consent. This also applies to transfer through property distribution, inheritance, testamentary disposition, company partition or similar acquisitions. 
There are certain exceptions to the main principle. A tenant who no longer intends to use his or her residential apartment may transfer the tenancy to a close relative (spouse, cohabitant or child) who lives with him or her on a permanent basis if the rent tribunal gives permission for the transfer. Such permission must be granted if the lessor can reasonably be satisfied with the change. The same applies if the tenant dies during the rental period and the estate wishes to transfer the tenancy to such an estate owner or another close relative of the tenant, who lived with him or her permanently.

There is also a possibility for the tenant to transfer the tenancy in order to obtain the tenancy for another residential apartment by exchange if the rent tribunal gives permission for the transfer. Permission must be granted if the tenant has notable reasons for the change and if it can take place without significant inconvenience to the lessor. However, if the tenant or the person to whom the tenancy is to be transferred has resided in his or her apartment for less than one year at the time of the application for a permit, permission only will be granted if there are special reasons for the exchange. Further, there is a ban on compensation in connection with transfers of tenancies (see below).

With regard to subletting the apartment, the tenant may not, without the lessor's consent, sublet or in any other way dispose of the apartment to someone else. There are also some exceptions to this restriction. The rent tribunal may, in certain cases, grant permission for subletting if the tenant has considerable reasons for the disposition due to special family circumstances, age, illness, temporary employment or studies in another locality, longer stay abroad or comparable conditions. An additional condition for a permit is that the lessor has no justifiable reason for refusing consent.

If the tenant does not comply with the above restrictions regarding the right to transfer and to sublet the tenancy, he or she may be liable for damages against the lessor, and, in addition, the tenancy can be forfeited, which means that the lessor can immediately terminate the tenancy agreement.

\subsubsection{The Right to the Value}

Anyone, who requests, enters into an agreement on or receives a special remuneration for letting a residential apartment or for transferring the tenancy to such an apartment can be fined or sentenced to up to four years of imprisonment. Such agreements are also criminal for the tenant. Anyone, who provides special remuneration or payments for renting a residential apartment or for acquiring the tenancy of such an apartment, can be fined or sentenced to up to four years of imprisonment.

A tenant, who sublets a residential apartment for independent use without the necessary consent of the lessor or permission from the rent tribunal and receives rent for the sublease that is not reasonable (see below), can be fined or sentenced to up to two years of imprisonment.

There are special provisions that regulate which rent may be charged for rental leases. In the case of residential rent, the so-called utility-value principle applies, which means that the rent must not significantly exceed the rent for other apartments, which, with regard to the utility-value - e.g., size, age, floor plan, standard, location, etc.- are equivalent. In the first instance, comparisons are made with other apartments in the locality; otherwise, the comparison may instead be made with apartments in another locality with a comparable rental situation and otherwise similar conditions in the rental market. In practice, the rent for a residential apartment is usually determined through collective bargaining between a property owners' organization and a tenants' association, usually at the municipal level [19]. Disputes about the rent can be adjudicated by the rent tribunal.

In the case of subleases, the following applies. If the rent for the subletting exceeds the rent paid by the lessor (the first tenant), in addition to furniture, equipment and other utilities, the rent shall never be considered reasonable. A supplement for furniture and other equipment included in the lease may not exceed 15 percent of the rent paid by the lessor. 
In the case of the new construction of residential apartments, there are exceptions to the utility-value principle. It is then possible for a lessor to meet an agreement with a tenants' association on rents that exceed the utility-value rent levels. Such rents are called presumptive rents and are valid for the first 15 years after construction. During that time, the presumptive rent cannot be examined and evaluated against the utility-value of the apartments by the rent tribunal. The presumption rent is often calculated on the basis of the apartments' production costs, which is normally higher than the utility-value. The purpose of these exceptions is to stimulate the production of new residential apartments [20].

\subsection{Tenant-Ownership}

The tenant-ownership form was introduced in 1930 as a part of the cooperative movement, creating a possibility to own an apartment instead of renting it. Today, the connection to the cooperative movement is limited.

The tenure is mainly regulated in the Bostadsrättslagen (tenant-ownership act) and the Lagen om ekonomiska föreningar (act on economic associations). A tenant-ownership association owns one or more buildings containing apartments and at times also a limited share of commercial space. Private persons buy shares in the tenant-ownership association and thereby receive the right to use a certain apartment without any limitation in time as long as they are members of the association. The members of the association appoint a board that represents the association and manages the property. The tenure is thus distinctly different from direct ownership of apartments as members of a tenant-ownership association jointly and severally own the economic association, which in turn owns the building(s). The economic association can take on debt and apply certain rules that all members must adhere to, also when it comes to the use of their individual apartments. The tenant-owner has the responsibility for maintaining the interior of the apartment, and the association is responsible for the management of the building, which is done in a cooperative manner.

The formation of new tenant-ownership associations occurs along one of two major lines, either through the conversion of existing buildings (usually rental housing) into tenant-ownership or through the construction of new buildings. A minimum of three members is required to form a tenant-ownership association. The tenant-ownership form has its roots in the cooperative movement, and at the outset, households planning to live in the apartments initiated projects. Today, commercial developers dominate as founders of tenant-ownership associations. Shares are then gradually sold to private persons, and at the completion of construction, board members appointed by the developer's hand over their responsibilities to a board appointed by the new owners, that is, mainly the households that plan to live in the apartments.

\subsubsection{The Right to Use and Exclude}

When using the apartment, a member and the persons the member is responsible for shall not disturb neighbors such that it harms health or impairs the housing environment to such an extent that it cannot be accepted. Further, the member shall respect the rules of conduct issued by the association according to local customs. A member may not house a third party in the apartment if it entails detriment to the association or any of its members. Should disturbances occur, the member shall be called to order.

The association has an obligation to manage the building and the common spaces. The tenant-owner is obliged to take care of the apartment. An owner may not make changes to load-bearing constructions or technical installations (sewage, heating, water and gas) or make any other essential changes in the apartment without the permission of the board of the association. The board may not refuse such consent unless it involves substantial harm or inconvenience to the association. Should the tenant-owner neglect his or her obligations to take care of the apartment to such an extent that this may impair the security of someone else or cause damage to someone else's property, the association may remedy the defect at the cost of the tenant-owner. 
Members of the association are admitted by the association board according to the law and to the statutes of the association. The tenant-owner can only use the apartment for the assigned purpose, and the association can only object to the use if it is of essential importance to the association or one of its members.

The statutes of the association can only be changed when a certain majority of members have voted for the change at one or two association meetings. The composition of required majorities to make a change to the statutes vary depending on the subject of the change.

Representatives of the tenant-ownership association and personnel hired by them have, under certain circumstances, the right to gain access to the apartment, typically to inspect technical installations or building parts or to carry out maintenance on the building.

The association may revoke the membership and the right to use the apartment in a number of specified situations, for example, in case the tenant-owner does not pay the monthly fee within a certain time frame, the apartment is sublet without the permission of the board, or the apartment is used for something else than it was intended to or in such a way that it is to the detriment to the association or any of its members. In case the membership and the right to use the apartment are revoked, the apartment will be the subject of a forced sale.

\subsubsection{The Right to Transfer}

Shares in tenant-ownership associations are traded freely on the open market without price regulations. However, new members of tenant-ownership associations need to be formally approved by the board according to the regulations of the association. Each association is free to formulate its own regulations, with some restrictions in the law, for example, related to discrimination and legitimacy. Changes to the statutes of the association that entail limitations to the right to transfer a share in the association require that all concerned owners agree to the change. A legal person can be denied membership even if the prerequisites for membership in the regulations of the association are fulfilled. A municipality or a region, on the other hand, can never be denied membership. When rental housing is sold to an association and converted into tenant-ownership, current tenants cannot (with a few exceptions) be denied membership in the association. Disputes are reverted to the rent tribunal. When a private or legal person has become a member of the association, the association must grant that person the right to use the specific apartment that is connected to the application for membership.

Should a member wish to renounce his or her membership in the association, this is allowed at the earliest two years after becoming a member and after written notice to the board. However, in case the renunciation is due to substantial increases in yearly fees, the tenant-owner may leave within three months, provided that this is not unreasonable in relation to the association and the other members. The association then becomes the owner of the shares and gets the right to use the apartment. A "reasonable compensation" shall be paid by the association. The former member is then freed of all his or her rights and obligations to the association.

Subletting of tenant-ownership apartments on a larger scale is not seen as a societal interest [21]. Typically, the purpose of a sublet is to allow the owner to live somewhere else for a limited period of time, for example, due to studies in another town, before he or she moves back into the apartment. The tenant-owner may not sublet the apartment without the consent of the board unless the owner is a municipality or a region or a legal person that has acquired the apartment after a forced sale and have a pledge on it. Legal persons are only allowed to sublet the apartment as a permanent dwelling. However, should the board deny a sublet, the rent tribunal can test the arguments of the parties and allow it for a certain period of time and under certain conditions. However, due to the housing shortage, it has been deemed of interest to quickly increase the number of available apartments. Hence, in 2014, the Lagen om uthyrning av egen bostad (act on letting private dwellings) was introduced. The law takes the presidency over Chapter 12 of the land code, which among other things, entails that the subtenant does not have any security of tenure. 


\subsubsection{The Right to the Value}

Moving away from the cost-based, nonspeculative transfer principles introduced in the 1930s, prices of tenant-ownership apartments were deregulated in 1968. Since then, owners are free to sell their shares and the accompanying right to use a specific apartment to the highest bidder, provided that the new owner is approved by the association. Conversions of rental housing into tenant-ownership are possible if there is a two-thirds majority among the tenants. In the 2000s, this has occurred mainly in attractive locations, which due to the rent-setting system, has entailed substantial wealth increases of tenants becoming tenant-owners.

A share in a tenant-ownership association can be mortgaged and used as security for a loan. No stamp duty is paid on transfers. Other taxes fall upon the association and not directly upon the shares in the association. Each tenant-owner shall pay certain fees to the association: a deposit for the share in the association, a yearly fee to cover running costs and if stipulated in the statutes, an entrance fee, a transfer fee, a pledge fee and a subletting fee. A change of yearly payments to the association by the shareholders must be approved at the general meeting of the association. The principles for division among shareholders of potential profit of the association shall be regulated in the status of the association, as shall the principle for the division of remaining assets in case of liquidation of the association. If the association is liquidated, the tenant-ownership ceases and is replaced by a rental contract.

In case a tenant-owner has a debt to the association, a forced sale may take place. The enforcement authority tries the case, and should it be deemed relevant, the sales will be made. The association has a right to receive payment from the sales price. Should a sale not be possible due to a lack of buyers, the share and the right to use the apartment will be transferred to the association.

Since the introduction of the Act on Letting of Private Dwellings in 2014, rents on sublet apartments are not tied to the utility-value rent-setting principles of first-hand rental apartments. Instead, the maximum rent is connected to the financing and management costs of the tenant-owner.

\subsection{Ownership}

In 2009, amendments allowing ownership of single apartments were introduced in the Fastighetsbildningslagen (real property formation act) in Sweden. The ownership apartment is a $3 \mathrm{D}$ property unit intended for just one single dwelling for housing purposes. It may not be formed for other purposes, such as offices or commercial purposes. The specific statutes for apartment ownership, added to the regulations for the traditional property units and the 3D property units, include the limitation that ownership apartments can only be created in new buildings or buildings not having been used for housing during the last eight years.

The main types of 3D property rights in the broad sense that can be found internationally are the independent 3D property, the condominium (apartment ownership), indirect ownership and granted rights [22]. Apartment ownership entails the use of a three-dimensional delimited part of a building and is a common and widespread form that exists all over the world in, e.g., Australia, Canada and South America (see, e.g., [22,23]). It usually includes three components, namely the ownership to a part of the building, a share in the common property and membership in an association for the management of the building. Two main forms of apartment ownership can be discerned, namely the condominium ownership type (dualistic form) and the condominium user right type (monistic form). The condominium ownership type means that each apartment owner owns the part of the building that he or she occupies, while the common parts of the building and surrounding land usually are owned jointly by all the owners of the building. The Swedish apartment ownership belongs to this type. 
The ownership apartment can be created in the same way as traditional real property by available cadastral procedures, such as subdivision, partition, amalgamation and reallotment. It is possible for a person to own several ownership apartments.

\subsubsection{The Right to Use and Exclude}

The right to use an ownership apartment is the same as for ownership of 2D and 3D property units. Ownership entitles to full disposal of the apartment. Interior alterations to the apartment can be made without the permission of the association. The ownership right contains the right to use the apartment, as well as access to the common parts of the building and the surrounding land, normally in the form of shares in a joint property comprising those common elements. However, the use of the common parts in the building is restricted by the share in the common property and the association rules. The right is thus far-reaching.

There are general rules for rights between neighbors that also apply to ownership apartments, as well as rules on allowing access to the adjacent property for the purpose of repairs, construction work, etc. There are also regulations to protect from insufficient maintenance by neighboring property owners or from damage to the apartment from an adjacent property. When disturbances occur among the residents, the association can take actions to solve them, and there may be house rules regulating the use of the common facilities. It is not possible for the apartment owner to lose their ownership right, but in case of disturbances caused by the owner, tenants or others using the apartment, the owner can be ordered under penalty that the disturbance should stop.

\subsubsection{The Right to Transfer}

The ownership of the apartment can be transferred without any restrictions in the same way as for ownership of $2 \mathrm{D}$ and other $3 \mathrm{D}$ property units. The ownership can be transferred to whomever the owner chooses at any agreed price. The share in the joint property for the surrounding building and land is transferred along with the property unit, and thus, there is no need for an application for membership in the association.

Subletting can be made freely without asking for permission from the association for the common parts of the building. The tenancy rules in the land code chapter 12 apply, following the rules for single- or two-family houses with weaker security of tenure.

\subsubsection{The Right to the Value}

The ownership apartments can be traded freely on the open market at market prices. Due to the still limited amount of existing ownership apartments, the market is rather small, and the price is usually higher than for a similar tenant-ownership apartment as no part of the debt can be absorbed by the association, as is normally the case in tenant-ownership. Thus, the owners themselves have the responsibility to pay for and finance their respective apartments. The apartment can be mortgaged and used as security for a loan. Stamp duty is paid on the purchase of the apartment and for issuing mortgage certificates if the apartment is mortgaged in the same way as other real property. The same tax rules apply to single-family houses.

The common property of the condominium apartments is normally jointly managed by the apartment owners through a joint property association. The apartment owners are members of the joint property association, which must comply with certain regulations when it comes to funding and maintenance of the common property. Costs related to the operation of the common spaces and facilities are allocated among the apartment owners, where some of the running costs may be separated on the apartment level. In order to finance construction, maintenance and renewal of the association's facilities, or if there is a need for the association to take another mortgage, charges may be levied from the members. In some cases, the association will set aside funds in reserve for the purpose of safeguarding maintenance and renewal of the joint facility within the common property. 
The ownership apartment can be used as an investment by subletting it, both by private persons and by companies. The amount of rent can be based on the market value of the apartment.

\section{Results}

Below, conditions related to the right to use, exclude and transfer, as well as the right to the value, will be discussed and analyzed using the proposed framework.

\subsection{The Right to Use and Exclude}

The duty of care of the apartment and consideration for others living in the building is similar in all tenure types. Everyone living in the building must properly take care of their own dwelling such that the use of the dwelling and its resulting physical condition does not negatively affect neighbors or the property owner. The tenant or the owner has responsibility for his or her family members and others who enter the property due to relation to him or her.

When it comes to the responsibility for the condition and standard of the apartment and the building, there are differences between tenancies and the two forms of ownership. A lessor has the responsibility to ascertain a certain level of maintenance and housing standard of both the apartment and the building. The tenant has a limited right to make changes to the apartment but needs the consent of the lessor and must pay damages in case changes are deemed to lessen the value of the property. Typically, only minor changes, such as painting or wallpapering, are allowed. The ownership forms clearly divide the responsibility for the building as a common good and the apartment as an individual responsibility. The joint associations have the responsibility for the maintenance of the commonly used land and parts of buildings. A tenant-owner or an owner is free to make changes in the apartment but needs the consent of the association to make larger changes that could have an impact on other tenant-owners/owners or the association.

The right to exclude is the same in all three tenure types, as the lessee or the owner has the right to prevent other persons from entering or using the apartment. Only in certain situations, the lessor or the associations responsible for common premises have the right to enter the apartment, typically connected to necessary control or maintenance of the building.

Under Swedish rental law, leases are typically unlimited in time, and tenants have direct protection of possession, which entails an, in international comparison, strong security of tenure. However, under certain conditions, usually tied to payment default or actions that are to the detriment of others living in the building, the tenant may be evicted. Similar rules apply to tenant-ownership, as tenant-owners may be dispossessed of their share in the association on similar grounds as when a tenant is evicted. In both cases, the rent tribunal tries the case. Owners, on the other hand, can only lose their right to use the apartment in case it is subject to a forced sale, e.g., due to bankruptcy. Disturbances and other unwanted behavior cannot result in dispossession. However, disputes with the association or other households in the building may result in penalties.

\subsection{The Right to Transfer}

Under Swedish law, a tenant has the right to transfer his or her rights to a rental apartment to another individual in exchange for a new dwelling. The new dwelling can be another rental apartment, a share in a tenant-ownership association or a single-family house. Further, rental agreements can be transferred to family members if they have lived in the apartment for a certain period. This rule applies not only to spouses and children but also to grandchildren.

Sales of shares in tenant-ownership associations are generally made on the open housing market. However, new owners must be approved by the tenant-ownership association. Ownership of single apartments can be transferred without restrictions. 
A tenant or a tenant-owner wishing to sublet his or her apartment needs the approval of the lessor or the tenant-ownership association. Rent levels are subject to caps in relation to the cost the lessee or the tenant-owner has for the apartment. Disputes are solved by the rent tribunal. In the case of ownership apartments, subletting is not subject to restrictions.

\subsection{The Right to the Value}

\subsubsection{Rental/Tenancy}

The rent level affects the distribution of the economic value that the property and the tenancy constitute between the lessor and the tenant. In the Swedish form of rent-setting system, the so-called utility-value system, rents are negotiated between a property owners' organization and a tenants association. Donner, Englund, and Persson [24] show that the system mainly results in below-market rents in the Stockholm region, i.e., a system that transfers part of the value of the apartment from the owner to the tenant. However, there are also cases when rents are above the appraised market rent, typically in less attractive areas, which entails that values are transferred from the tenant to the lessor.

A tenancy is obviously an asset with both economic and social value, both for the lessor and the tenant. However, the Swedish legislation stipulates a fundamental and concrete prohibition against realizing this value through various forms of remunerations or payments in the case of granting leases to the lessor or in the case of transfers and subleases to the tenant. Such dispositions are illegal and subject to criminal sanctions. In 2019, these sanctions were considerably extended due to problems with illegal subletting and lease contract trade [25].

\subsubsection{Tenant-Ownership}

When the tenant-ownership system was introduced, shares in cooperatives could not be freely traded but only sold at the same price as had been originally paid for the shares. This rule had the distinct aim of avoiding housing speculation. However, as tenantownership became the only form of individual ownership in Swedish multifamily housing, this rule was abolished, and shares were allowed to be traded on the open market from 1968 onwards [26]. This decision had a large impact on the financial standing of many households, as they over-night were given the right to the value of their apartment when transferred. The right to sublet, however, remained restricted, limiting the right of the owner to rental income from his or her property.

As described above, in 2014, a new law was introduced with the aim to make subletting of tenant-ownership apartments easier and more profitable in an attempt to reduce the housing shortage. Previously, utility-value rents were to be applied, but under the new legislation, tenant-owners may charge a rent equivalent to the financing and management cost of the apartment [21]. The initiative has resulted in more apartments being let, but also in higher rents in many areas.

\subsubsection{Ownership}

Ownership of apartments for individual use was introduced in Sweden in 2009. It was done in an attempt to spur the construction of new housing but also to strengthen private ownership in multifamily housing [27]. Such ownership can be transferred without restrictions. It is also allowed to sublet ownership apartments at market rent and without approval.

The right to value is influenced by the illiquid market for ownership apartments. Reasons for the limited amounts of ownership apartments is probably that many individual buyers are unfamiliar with this form of tenure and that up-front payments at acquisition are usually higher than for the equivalent share in a tenant-ownership association (where the association takes on parts of the financing). 


\subsection{Analyzing Similarities and Differences between the Tenures}

In this section, the theoretical framework presented above is applied to Swedish multifamily housing in order to summarize the bundle of rights connected to each of them (Table 1).

Table 1. Property rights characteristics of the three tenure forms.

\begin{tabular}{|c|c|c|c|c|}
\hline & & Ownership & $\begin{array}{c}\text { Tenant- } \\
\text { Ownership }\end{array}$ & Rental \\
\hline \multirow{7}{*}{$\begin{array}{l}\text { The right to use } \\
\text { and exclude }\end{array}$} & The duty of care and consideration & $x$ & $x$ & $x$ \\
\hline & $\begin{array}{l}\text { The responsibility for the condition } \\
\text { and standard of the apartment }\end{array}$ & $X$ & $X$ & $X$ \\
\hline & $\begin{array}{l}\text { The responsibility for the condition } \\
\text { and standard of the building }\end{array}$ & $x$ & $(\mathrm{X})$ & - \\
\hline & The right to current use & $X$ & $X$ & $x$ \\
\hline & The right to altered use & $x$ & $(X)$ & - \\
\hline & The right to exclude & $X$ & $X$ & $X$ \\
\hline & Security of tenure & $X$ & $(X)$ & $(\mathrm{X})$ \\
\hline \multirow{2}{*}{$\begin{array}{l}\text { The right to } \\
\text { transfer }\end{array}$} & The apartment & $X$ & $X$ & - \\
\hline & Subletting & $x$ & $(\mathrm{X})$ & $(X)$ \\
\hline \multirow{3}{*}{$\begin{array}{c}\text { The right to the } \\
\text { value }\end{array}$} & Transfer price & $x$ & $x$ & - \\
\hline & Rent and management costs & $x$ & $x$ & $(X)$ \\
\hline & Income from subletting & $X$ & $(X)$ & - \\
\hline
\end{tabular}

Legend: $X=$ full rights and responsibilities; $(X)$ = rights and responsibilities with some restrictions; $-=$ no rights or responsibilities.

As seen above, there is a sliding scale between the three forms of tenure with no clear lines between the forms when it comes to some of the characteristics. Not unexpectedly, ownership of single apartments has the strongest ownership rights under Swedish law and owners enjoy all the rights. However, ownership has only been possible since 2009 and is also the least common tenure. To own shares in a tenant-ownership association is the most common form of individual ownership of apartments in Sweden, although it should be noted that the ownership is indirect. In this form of ownership, the right to use and to transfer, as well as the right to the value, are partially restricted through the rights of the tenant-ownership association (and consequently the other tenant-owners). Swedish rental housing has some distinct features, which leads to that it lies closer to ownership than rental in many other countries. Apart from the right to use and the right to exclude, which are common in most rental systems, there is strong security of tenure, a limited right to transfer and a potential right to value. The potential right to value stems from the rent-setting system and the legal right to transfer under certain circumstances. The ownership rights of private and public lessors decrease in importance as a result of the increase experienced by tenants. The largest differences in the bundles of rights of the three tenures are connected to the right to the value: apart from the rent-setting principles described above, transfer price and income from subletting are guided by market levels for the two ownership forms, while nonprofit principles apply to rental contracts.

The sliding scale between rental and tenant-ownership can be explained by the historical development of the two tenure forms: Initially, tenant-ownership apartments were not intended to be seen as investments but as a complement to the rental market. Current similarities between the tenures related to restrictions on use and subletting, the risk of losing the right due to unwanted behavior, the role of the rent tribunal, etc., should be seen in this light. However, since the price deregulation and the introduction of the utility-value system in the 1960s, the two tenures have separated into two different paths when it comes to the right to the value. Whereas the utility-value system sees that rents are restricted in 
comparison to supposed market levels, the market for tenant-ownership shares has thrived. The HOX house price index notes an increase from 100 in 2005 to 308 in 2020 [28]. In 2014, subletting of tenant-ownership apartments has been made easier and more profitable, which increases the right to the value of tenant-owners.

The introduction of apartment ownership in 2009 was partly motivated by the fact that the cooperative nature of tenant-ownership was gradually being eroded and had moved closer to pure ownership, e.g., when it comes to purchasing price, mortgaging and the influence residents have over their accommodation, which could be prevented by allowing apartment ownership as a parallel form and thus separating the two further [29]. However, such a distinction has not materialized. Paulsson [4] compares the Swedish 3D property types with the international standard types of 3D property and argues that in comparison with these standard types, the Swedish forms are very similar to each other. This is suggested as one of the possible reasons for why apartment ownership has not yet been used to any larger extent in Sweden, since the forms may not be clear enough in themselves and between each other, with the result that it will be difficult to understand how to use them and how to choose between them.

In the next step, more empirical material could be added to the above to test the suggested framework further.

\section{Conclusions and Future Research}

The sliding scale between usufruct and ownership was elucidated through the application of a property rights framework applied to three Swedish forms of tenure. The employed approach deconstructs the bundle of rights for the tenure forms, making the comparison and analysis more transparent and structured. It was concluded that the tenures have many commonalities but that there are distinct differences connected to the right to the value.

As stated in the introduction, this is the first stage of a larger research project. The herein presented framework will serve as a basis in the development of a framework able to catch more facets of tenure regulation and related outcomes. In the next steps, the framework and its application are to be tested and developed. The framework should also be supplemented by other components addressing influences beyond formal property rights as well as distributional effects related to different property rights outcomes. Below, ongoing and planned research is outlined:

Future research could test whether the property rights framework may be applicable also on a general level as a method to analyze and compare tenures of different types in different countries. The proposed property rights framework has been applied to three distinct formal forms of Swedish tenure within multifamily housing. If applied to other tenure forms or rural conditions, as well as international forms, the range of variables may need to be adjusted, as these will reflect local conditions [30]. If evaluating tenure forms that are not that distinct, it would be useful to consider the continuum of land rights [31] when the rights are more fluid and continually changing and where existing frameworks may not be applicable. There are also more stable continuum forms that create difficulties in being evaluated based on the framework, such as customary rights and rural lands with ambiguous interests, for more informal rights, such as customary or religious tenure systems where there will be a need to identify the responsibilities and obligations connected with these and the possible social and cultural variations. The local context may thus affect the tenure forms, and they may change when government or policy is changed (30). This would be further developed when making international case studies as a further step in the research project.

Currently, a comparative study of tenure forms in the Nordic countries is ongoing. A developed framework may be used to better understand the gaps between dominant tenures that have induced attempts to create new hybrid forms of tenure, often trying to address affordability issues. This study will also capture if other Nordic countries, which 
in many respects have similar legal systems as Sweden, also experience the advancement of apartment ownership forms towards a virtually absolute ownership model.

Moreover, additional parameters could be included in the analysis. One example of such parameters is taxation. The herein analyzed right to the value does not include taxation, although taxation is expected to have additional implications for the right to the value. As the next step in the analysis, relevant taxes could also be included.

As pointed out above, the presented framework based on a bundle of rights perspective is a tool to analyze the formal distribution of rights under a specific housing regime. However, it is recognized that the influence of formal rules and regulations may have different weight in different historical and cultural contexts. Further, the framework has its limits when it comes to elucidating the socio-political effects of the distribution over time. Additions to the theoretical framework should be made to cover distributional consequences and influences beyond formal property rights. Ongoing research on the historical development of the Swedish tenure forms, and the negotiations between the state, property owners and political entrepreneurs that have shaped them, could contribute to a deeper understanding of today's situation, especially in relation to why property rights have been allocated according to various patterns over time. Building on the above studies, distributional patterns of the existing allocation of property rights could be analyzed, preferably in a cross-country context.

Author Contributions: Conceptualization, A.G.H. and P.E.; formal analysis, A.G.H., P.E. and J.P.; methodology, J.P.; project administration, A.G.H.; writing—original draft, A.G.H., P.E. and J.P. All authors have read and agreed to the published version of the manuscript.

Funding: This research received no external funding.

Conflicts of Interest: The authors declare no conflict of interest.

\section{References}

1. Statistics Sweden. Boende i Sverige. 2020. Available online: https://www.scb.se/hitta-statistik/sverige-i-siffror/manniskorna-isverige/boende-i-sverige/ (accessed on 22 June 2020).

2. Statistics Sweden. Fastighetsbeståndet (The housing stock). 2020. Available online: https://www.scb.se/hitta-statistik/statistikefter-amne/boende-byggande-och-bebyggelse/bostadsbyggande-och-ombyggnad/bostadsbestand/pong/statistiknyhet/ bostadsbestandet-2019-12-31/ (accessed on 22 June 2020).

3. Lantmäteriet. Fastighetsregistret Halvårsstatistik år 2020. 2020. Available online: https:/ /www.lantmateriet.se/contentassets/c1 d61031f786423cb72a0529bd5d2e2d/halvarsstatistik_2020.pdf (accessed on 1 November 2020).

4. Paulsson, J. Swedish 3D Property in an International Comparison. In Proceedings of the 3rd International Workshop on 3D Cadastres: Development and Practices, Shenzhen, China, 25-26 October 2012; van Oosterom, P., Guo, R., Li, L., Ying, S., Angsüsser, S., Eds.; International Federation of Surveyors (FIG): Copenhagen, Denmark, 2012; pp. 23-40.

5. Ekbäck, P. Private, Common, and Open Access Property Rights in Land-An Investigation of Economic Principles and Legislation. Nord. J. Surv. Real Estate Res. 2009, 6, 57-74.

6. Anderson, T.L.; McChesney, F.S. (Eds.) Property Rights. Cooperation, Conflict and Law; Princeton University Press: Princeton, NJ, USA, 2003.

7. Alchian, A.; Demsetz, H. The Property Rights Paradigm. J. Econ. Hist. 1973, 33, 16-27. [CrossRef]

8. Demsetz, H. Toward a theory of property rights. Am. Econ. Rev. 1967, 57, 347-359.

9. Hurndall, A. Property in Europe: Law and Practice; Tottel Publishing: West Sussex, UK, 1998.

10. Needham, D.B. Institutions for housing supply. In International Encyclopedia of Housing and Home; Smith, S.J., Elsinga, M., Fox O'Mahony, L., Eds.; Elsevier: Oxford, UK, 2012; pp. 99-108.

11. Snare, F. The Concept of Property. Am. Philos. Q. 1972, 9, 200-206.

12. Bergström, S. Om begreppet äganderätt i fastighetsrätten. Sven. Juristtidning 1956, 10, 145-162.

13. Hodgson, G.M. What are institutions? J.Econ. Issues 2006, 40, 1-25. [CrossRef]

14. North, D. Institutions, Institutional Change, and Economic Performance; Cambridge University Press: New York, NY, USA, 1990.

15. Mandič, S.; Filipovič Hrast, M. Homeownership in multi-apartment buildings: Control beyond property rights. Hous. Theory Soc. 2019, 36, 401-425. [CrossRef]

16. Libecap, G.D. Contracting for Property Rights; Cambridge University: Cambridge, MA, USA, 1989.

17. Grossi, D.; Dignum, F. From Abstract to Concrete Norms in Agent Institutions. In FAABS; Hinchey, M.G., Ed.; Springer: Berlin, Germany, 2005; Volume 3228, pp. 12-29. 
18. Bengtsson, B.; Hager, R.; Victorin, A. Hyra Och Annan Nyttjanderätt till Fast Egendom; 9 uppl; Norstedts Juridik: Stockholm, Sweden, 2018.

19. Bergendahl, P.-A.; Hjeds Löfmark, M.; Lind, H. Bostadsmarknaden och Den Ekonomiska Utvecklingen; Bilaga 3 till Långtidsutredningen 2015; SOU 2015:48; Swedish Government Offices: Stockholm, Sweden, 2015.

20. Proposition [Government's bill to the Parliament] 2005/06:80 Reformerad hyressättning; Swedish Government Offices: Stockholm, Sweden, 2005.

21. Flodin, J.; Victorin, A. Bostadsrätt Med en Översikt Över Kooperativ Hyresrätt, 5th ed.; Iustus Förlag: Uppsala, Sweden, 2020.

22. Paulsson, J. 3D Property Rights—An Analysis of Key Factors Based on International Experience; Doctoral Thesis, Report 4:99. Section of Real Estate Planning and Land Law; KTH Royal Institute of Technology: Stockholm, Sweden, 2007.

23. van der Merwe, C.G. Apartment ownership. Chapter 5. In International Encyclopedia of Comparative Law; Property and trust; Yiannopoulos, A.N., Ed.; Mohr: Tübingen, Germany, 1994; Volume 6.

24. Donner, H.; Englund, P.; Persson, M. Distributional Effects of Deregulating the Stockholm Rental Housing Market; Swedish Fiscal policy Council: Stockholm, Sweden, 2017.

25. SOU [Swedish Government Inquiries] 2017:86. Hyresmarknad Utan Svarthandel Och Otillåten Andrahandsuthyrning; Betänkande av Utredningen om åtgärder mot handel med hyreskontrakt; Swedish Government Offices: Stockholm, Sweden, 2018.

26. Sørvoll, J.; Bengtsson, B. The Pyrrhic victory of civil society housing? Co-operative housing in Sweden and Norway. Int. J. Hous. Policy 2018, 18, 124-142. [CrossRef]

27. Proposition [Government's bill to the Parliament] 2008/09:91. Ägarlägenheter; Swedish Government Offices: Stockholm, Sweden, 2009.

28. Valueguard. Bostadsrätter Sverige. 2020. Available online: https:/ / www.valueguard.se/indexes (accessed on 30 October 2020).

29. SOU [Swedish Government Inquiries] 2002:21. Att Äga Sin Lägenhet; Betänkande av 2000 års Ägarlägenhetsutredning. Swedish Government Offices: Stockholm, Sweden, 2002.

30. Payne, G. Land tenure and property rights: An introduction. Habitat Int. 2004, 28, 167-179. [CrossRef]

31. UN-Habitat. Framework for Evaluating Continuum of Land Rights Scenarios; Report 4/2016; UN-Habitat: Nairobi, Kenya, 2016. 